УДК 78.304.2](477.43)«19»

\author{
Сізова Нінель Степанівна, \\ https://orcid.org/0000-0003-1622-719X \\ викладач кафедри вокально-хорової підготовки, \\ теорії та методики музичної освіти, \\ Вінницький педагогічний університет \\ імені М. Кочюбинського, \\ Віниия, Україна, \\ sizova1980@ukr.net
}

\title{
КОНЦЕРТНО-МУЗИЧНЕ ЖИТТЯ ВІННИЦІ ПЕРШОЇ ТРЕТИНИ ХХ СТОЛІТТЯ
}

Мета роботи. У статті досліджено специфіку концертного життя міста Вінниці початку XX ст. Визначено роль хорових колективів, оркестрів та окремих виконавців у процесі становлення професійного музичного мистецтва Вінниччини. Охарактеризовано особливості творчої діяльності хорових колективів міста та області, зокрема художньої капели Григорія Давидовського та симфонічного оркестру міста. Визначений вплив окремих творчих постатей на концертно-музичне життя міста. Окремо розглянута діяльність Вінницького музичного технікуму, особливості його роботи, вплив викладачів технікуму на творче життя міста. Методи дослідження полягають у застосуванні культурологічного підходу й системного методу, завдяки чому можна виявити особливості розвитку музичного мистецтва Вінниччини як підсистеми культурної системи регіону та України загалом. Культурологічний підхід дозволяє також проаналізувати особливості професіоналізації музичного мистецтва краю в контексті загальної культурної-історичної ситуації першої третини XX ст. Наукова новизна полягає в оприлюдненні матеріалів з архівних фондів, які дозволяють відтворити специфіку музичного життя Вінниччини. Зокрема, наведено нові факти з діяльності хорових колективів, оркестрів та окремих виконавців. Висновки. Результати дослідження дозволяють зробити висновок, що концертне життя Вінниччини початку XX ст. було широко представлене власними колективами міста, гастролюючими колективами й окремими виконавцями та було насиченим і різноманітним. Різнобічне дослідження діяльності творчих колективів Вінниччини першої третини XX ст., їх орієнтації на певну аудиторію дозволяє усвідомити специфіку процесу професіоналізації хорового мистецтва краю як складової самобутнього образу регіональної музичної культури.

Ключові слова: хорова культура Вінниччини, хоровий колектив, концертна діяльність, хоровий спів, музична освіта.

Сизова Нинель Степановна, преподаватель кафедры вокально-хоровой подготовки, теории и методики музыкального образования, Винниикий педагогический университет имени М. Коџюбинского, Винница, Украина

Концертно-музыкальная жизнь Винницы первой трети XX века 
Цель работы. В статье исследована специфіка концертной жизни города Винницы начала XX века. Определена роль хорових коллективов, оркестров и отдельных исполнителей в процес се становлення профессионального музикального искусства Винницкой области. Охарактеризованы особенности творче ской деятельности хорових коллективов города и области, в частности художественной капеллы Григория Давидовского и симфонического оркестра города. Определено влияние отдельных творческих личностей на концертномузыкальную жизнь города. Отдельно рассмотрена деятельность Винницкого музикального техникума, особенности его работы, влияние преподавателей техникума на творче скую жизнь города. Методы исследования заключается в применении культурологического подхода и системного метода, благодаря чему можно определить особенности развития музикального искусства Винницкой области как подсистемы культурной системы региона и Украины в целом. Культурологический поход позволяет также проанализировать особенности профессионализма музикального искусства края в контексте общей культурной исторической ситуации первуй трети XX века. Научная новизна заключается в обнародовании материалов из архивных фондов, которые позволяют воспроизвести специфику музыкальной жизни Винницко йобласти. В частности приведены нове факты из деятельности хорових коллективов, оркестров и отдельных исполнителей. Выводы. Результаты исследования позволяют сделать вывод, что концертная жизнь Винници в начале XX в. была широко представлена собственными колективами города, гастролирующими коллективами и отдельными исполнителями и являлась насыщенной и разнообразной. Разносторонне еисследование деятельности творческих коллективов Винници первуй трети XX в., их ориентации на определенную аудиторию позволяет осознать специфіку процесса профессионализма хорового искусства края как составляющей самобытного образа региональной музыкальной культуры.

Ключевые слова: хоровая культура Винницкой области, хоровой коллектив, концертная деятельность, хоровое пение, музыкальное образование.

Sizova Ninel, Teacher at the Department of Vocal and Choral Performance, Theory and Methodology of Musical Education, Vinnytsia State Pedagogical University named after M. Kotsiubynsky, Vinnytsia, Ukraine

\section{Concert and musical life of Vinnytsia in the first third of the 20th century}

The purpose of the article is to study the specifics of the concert life of Vinnytsia at the beginning of the 20th century; to determine the role of choirs, orchestras and individual performers in the process of formation of professional music art of Vinnytsia region; to characterize the peculiarities of the creative activity of choirs of the city and the region, and, in particular, Hrygorii Davydovskyi's artistic chapel and the symphonic orchestra of Vinnytsia; to reveal the influence of individual creative figures on the concert and musical life of the city; to explore the activity of Vinnytsia Music College, the features of its work, and the influence of the teachers of the college on the creative life of the city. 
The research methodology consisted in the cultural approach and the systemic method, which made it possible to identify the peculiarities of the development of music art of Vinnytsia as a subsystem of the cultural system of the region and Ukraine as a whole. The cultural approach also allowed for analyzing the features of professionalization of music art of the region in the context of the general cultural and historical situation of the first third of the 20th century.

The scientific novelty of the work lies in the publication of archival materials which allow for reproducing the specifics of the musical life of Vinnytsia. In particular, new facts about the activity of choirs, orchestras and individual performers were presented.

Conclusions. The results of the study suggest that the concert life of Vinnytsia region at the beginning of the 20th century was widely represented by city's ensembles, touring collectives and individual performers, and was saturated and diverse. The versatile study of the activity of creative teams of Vinnytsia in the first third of the 20th century and their orientation towards certain audiences makes it possible to understand the specifics of the process of professionalization of choral art of the region as a component of the original image of regional musical culture.

Key words: choral culture of Vinnytsia region, choir, concert activity, choral singing, musical education.

Вступ. Кін. XIX - поч. XX ст. характеризується активними процесами професіоналізації різноманітних галузей музичного життя України. Так, у переважної більшості міст інтенсивно розвивається фортепіанне, хорове, камерно-інструментальне та камерно-вокальне музикування. Найчастіше відбуваються концерти симфонічної та хорової музики. Музичні вечори проходять у Києві, Одесі, Львові, Чернігові, Житомирі та ін. українських містах. Концертно-музичне життя Вінниччини $\epsilon$ одним із найбільш малодосліджених тем, що і підтверджує актуальність вибору даного дослідження.

Аналіз останніх досліджень і публікацій. Дослідження концертної діяльності колективів дозволяе створити повну картину музичного життя певного регіону. Вивчаючи специфіку регіональних музичних культур, науковці наголошують на тому, що культурно-мистецьке життя регіонів України $є$ такою складовою національної художньої культури, яка вже утворила міцну систему та набула рис професіоналізації на всіх її структурних рівнях. Серед різноманіття культурологічних і мистецтвознавчих досліджень, присвячених комплексному вивченню регіональної культури або окремих складових iї мистецького життя виділяємо наукові роботи [2], Г. Борейко [3].

Постановка наукової проблеми. Хоча окремі аспекти представлені у роботах М. Антошко [1], Т. Бурдейної-Публіки [4], О. Черкашиної [20], тематика концертного життя Вінниці поч. XX ст. та його впливу на культурні процеси $є$ найменш дослідженими. Зокрема, це стосується творчості хорових колективів, їх концертна діяльність, репертуар. У статті вперше висвітлюється музична діяльність Літературно-артистичного товариства, Артистичного клубу 
та клубу «Рідна хата», творчість яких залишається поза увагою дослідників музичного життя вінницького регіону.

Формулювання цілей статті. Спираючись на матеріали, що містяться в Державному архіві Вінницької області, автор статті ставить за мету систематизувати діяльність творчих колективів Вінниччини, особливості гастрольної діяльності, визначити вплив окремих виконавців на культурне життя міста та області.

Виклад основного матеріалу. Ключовими подіями, що скерували усе мистецьке життя України й Вінниччини першої третини XX ст., були Перша світова війна, національно-визвольні змагання і встановлення «совєцької» влади 3 їі нетривалою політикою українізації. Діячі Центральної Ради, Гетьманщини, Директорії відстоювали принципи незалежності як української держави, так і iї культури. Радянська влада, обравши класовий принцип розвитку культури, в 1920-ті роки певний час підтримувала курс українізації, демонструючи толерантне ставлення до культурних потреб українського народу.

У рік початку Першої світової війни Вінниця була адміністративним центром Подільської губернії, що сприяло пожвавленню іiі музичного життя. У місті й до цієї події постійно відбувалися гастролі окремих виконавців і колективів, функціонували заклади початкової музичної освіти, працював учительський інститут, в якому діяв студентський хор, здійснювалися музичнотеатральні постановки аматорськими й професійними трупами українською мовою. Все це сприяло становленню національної музичної культури зі своїми самобутніми рисами.

Суттєві зрушення відбуваються і в галузі музичного життя України. У Києві створено «Музичну драму», Українську державну хорову капелу під керівництвом О. Кошиця і К. Стеценка, Український державний симфонічний оркестр ім. М. Лисенка та багато ін. професійних колективів. Із столиці процес активізації культурно-мистецького життя досить швидко розповсюдився на периферію України, зокрема й до Вінниці. У провінційних містах і селах виникає низка самодіяльних хорових i музично-драматичних колективів, діяльність яких зосереджується навколо культурно-просвітницьких закладів та осередків.

У розкритті музичного життя Вінниччини протягом 1917-1920 рр. варто врахувати бурхливі події, які відбувалися в даному краї. У цей період постійної зміни влади iї утримували то революційні комітети, то ставленики австроугорських військ, то генерали денікінської армії. Під час подій української революції з листопада 1918 р. - травень 1920 р. місто Вінниця декілька разів було столицею України, місцем, де перебували урядові структури Української Народної Республіки (УНР). Так, з 5 лютого - 6 березня 1919 рр. і з травня по 9 червня 1920 р. у Вінниці перебував найвищий орган державної влади Директорія УНР.

Незважаючи на усі складності перших визвольних змагань, на Вінниччині культурно-мистецьке життя було досить інтенсивним. Місцева преса неодноразово коментує концерти російських піаністів i вокалістів, що гастролювали в місті. Поміж місцевих виконавців згадується про концерти 
української пісні в липні 1918 р. у Вінниці хору, організованого вчителями Вінницького, Літинського й Летичівського народних училищ. Окрім народних пісень, учительський хор виконував твори українських композиторів М. Лисенка, К. Стеценка, М. Леонтовича, О. Кошиця [14]. Сам репертуар колективу, що виступив під орудою Б. Левицького, свідчить про тогочасні прагнення до виховання національного духу слухачів.

Особливо насиченим концертне життя міста було в період Гетьманату. 3 місцевої преси стає відомо про концерти артистів московського Большого театру, ансамблю Московський фарс, Королівської фронтової трупи 3 Угорщини, вокалісти Клари Юнг з єврейською трупою оперети зі Сполучених Штатів Америки, київського театру «Дім інтермедії». Окрім професійних колективів, до міста приїздили аматорські польські та єврейські акторські трупи. Майданчиками для виступу артистів були приміщення місцевого театру, Білої зали Народного дому, Літнього театру, актові зали міських гімназій.

На Вінниччині активне культурно-мистецьке життя продовжується й після остаточного встановлення в Україні більшовицької влади в листопаді 1920 p. Більшовики, бажаючи завоювати серед різних національностей прибічників своєї ідеології, оголосили принцип національної рівності, наказуючи членам своєї партії сприяти розвитку української культури. Таким чином, було розпочато нетривалий процес українізації. Він торкнувся, насамперед, системи народної освіти і видавничої справи, а також активізації творчої діяльності населення. У Вінниці це проявилося не лише в появі українських шкіл, але й в розвитку клубної діяльності. Лише протягом 19191924 рр. у місті діяв двадцять один клубний заклад [8]. В Артистичному клубі, заснованому в 1919 р., постійно виступав квартет С. Обермана, а в клубі «Рідна хата» - струнний оркестр.

Тексти постанов, протоколів та звітів губернського виконавського комітету за 1919 р. свідчать, що у Вінниці було організовано оркестр, до складу якого увійшли 24 місцевих музикантів та диригент. Для поповнення складу оркестру та створення при ньому нотної бібліотеки було відправлено диригента у відрядження до Києва. Розпочалася робота над сюїтою з музики до драми «Пер Гюнт» Е. Гріга, Увертюрою до опери «Тангейзер» Р. Вагнера та ін. творами. Також було запроваджено «Історичний цикл популярних камерних концертів-лекцій», завданням якого була популяризація класичної камерної музики та прагнення відобразити «наочну» історію розвитку музики [13, арк. 25].

1919 р. був особливо складним як для усієї України, так і для Вінниччини. На нетривалий період влітку 1919 р. армія УНР разом з Галицькою Армією змогла звільнити від більшовиків усю Правобережну Україну. Публікації газети «Шлях» дозволяють відтворити історію концертного життя міста цього періоду. У Вінниці влада УНР була відновлена 10 серпня 1919 р. А вже 15 серпня цього року в газеті «Шлях» міститься оголошення про відновлення щоденних концертів великого симфонічного оркестру Товариства «Просвіта» під орудою Б. Крижановського [16]. У місцевій періодиці міститься й інформація про спільний концерт симфонічного оркестру зі зразковим учнівським хором під керівництвом М. Коломійцева [15]. 
За два тижні після вступу українського війська до Вінниці в міському театрі відбувся й перший концерт Художньої капели Г. Давидовського, до програми якого входили твори хормейстера - поема «Україна», фантазії «Бандура» $\mathrm{i}$ «Кобза», уривки з опери «Під звуки рідної пісні», а також гімн «Ще не вмерла Україна» в гармонізації Г. Давидовського [17]. У концерті взяла участь солістка Львівської опери А. І. Козак, яка певний час мешкала у Вінниці й провадила активну концертну діяльність [18].

Продовжувало діяти у Вінниці Літературно-артистичне товариство, засноване 1908 р., при якому в 1919 р. було організовано оперний хор. У газеті «Шлях» від вересня 1919 р. розміщено оголошення про набір дитячих голосів до концертного хору, до якого запрошувалися дітей віком до п'ятнадцяти років [19].

У звіті секції МУЗО за 1919 р. міститься одна з перших згадок про організацію хорових колективів: «Здійснені реальні кроки до організації художньої капели, Народного i Дитячого хору, запрошені керівники і викладачі. Оголошено набір до хорів та проби голосів, розпочато розписування нот. У найближчий час капела і хори приступлять до роботи» [6, арк. 52]. Саме там наголошується про те, що для учасників хорових колективів здійснюється викладання сольного співу й теоретичних дисциплін, яке в майбутньому закладе підвалини Народної консерваторії [6]. Зі звіту радянських владних органів стає відомо, що дитячий хор здійснював концертні виступи у березні 1922 р. [5, арк. 19].

У звіті також вказується програма одного 3 концертів квартету під керівництвом Антона Гуммеля. 3 програми стає зрозумілою культурно-освітня спрямованість роботи квартету, адже ії основу складають транскрипції світової симфонічної класики. Так, квартет виконував увертюру до опери Р. Вагнера «Нюрнберзькі мейстерзінгери», уривки з П’ятої симфонії Л. ван Бетховена, увертюру Ф. Мендельсона «Сон літньої ночі», Четверту симфонію Й. Гайдна. Варто зазначити, що сам скрипаль Антон Йосипович Гуммель зробив значний внесок у розвиток музичного життя Вінниччини 1920-х рр. Випускник Празької консерваторії, він працював вчителем музики в Празі, концертмейстером опери в Амстердамі й Будапешті, придворним капельмейстером у Софії. У 1898 р. А. Гуммель став капельмейстером 47-го піхотного українського полку, що знаходився у Вінниці. У місті він викладав у багатьох навчальних закладах, а також організував оркестр у вінницькій окружній лікарні для психічнохворих. Саме А.Гуммель у середині січня 1918 р. при владі солдатських рад і робітничих депутатів відкрив у місті музичне училище. Після закриття училища він завідував музичною школою при Тиврівській трудовій школі та викладав музику і співи на трирічних педагогічних курсах у Тиврові.

Розвитку безпосередньо хорового мистецтва у Вінниці сприяла й діяльність у місті у 1920-их рр. Музичного технікуму та оперного театру. Музичний технікум виник після реорганізації консерваторії в 1921 р. У зв'язку 3 тим, що випускники технікуму були спрямовані не тільки на виконавську, але й педагогічну діяльність, до складу навчального плану були введені загальна педагогіка, психологія, методика викладання, естетика ті ін. дисципліни 
[9, арк. 19]. Станом на перший навчальний рік у Музичному технікумі працювало 14 викладачів і навчалося 152 студенти віком від 18-31 років.

Серед обов'язкових навчальних дисциплін Музичного технікуму були й заняття 3 хору (жіночого і мішаного), на які відводилося вісім академічних годин на тиждень [там саме, арк. 44].

У фондах Державного архіву Вінницької області зберігаються навчальні програми для усіх спеціальностей, з яких відбувалася підготовка фахівців. Так, на випускному екзамені у класі вокалу студенти повинні були виконати арію і два романси та вже мати в репертуарі напам'ять не менш, аніж п'ять вокальних партій для свого голосу [9, арк. 4]. Одним з викладачів вокалу була відома співачка М. Литвиненко-Вольгемут, яка протягом 1919-1922 рр. була солісткою оперного театру у Вінниці. Працюючи у Вінниці, М. ЛитвиненкоВольгемут виховала майже весь тогочасний склад капели ім. М. Леонтовича. У 1922 р. до класу сольного співу не вступило жодного учня, тому М. Литвененко-Вольгемут був відрахований зі складу викладачів Музичного технікуму [там саме, арк. 76].

Значну роль у підготовці музикантів відводили заняттям з сольфеджіо. Зокрема, окрім співу в ключах «соль» і «фа», студенти повинні були опанувати сольфеджування у ключах «до» (сопрановому, альтовому і теноровому), співати акорди з оберненнями в ладу і поза ладом, альтеровані акорди. На екзамені студенти повинні були продемонструвати навички вільного читання з аркушу у всіх п'яти ключах, визначати акорди на слух та розв'язувати їх голосом, співати сольфеджіо в дуеті та тріо, а також записати двоголосний диктант [там саме, арк. 6].

Студенти усіх спеціальностей протягом усього періоду навчання опановували гру на фортепіано (навчальна дисципліна називалася «обов'язкове фортепіано»). У програмі містяться вимоги до гри гам, зокрема хроматичних. Цікаво, що навіть у класі обов'язкового фортепіано гами необхідно було виконувати не лише в октаву, але й терцію, сексту та дециму та в протилежному русі. Окрім гам, виконували арпеджіо, вправи та етюди. Вже на третьому році навчання студенти виконували нескладні сонати Й. Гайдна, В. Моцарта. На останніх курсах обов'язковим було вивчення інвенцій Й. С. Баха, гра акомпанементу, а також читання квартетних, хорових та оркестрових партитур [9, арк. 7].

Протягом двох навчальних років у Музичному технікумі вивчали теорію музики. 3 аналізу програми стає очевидним чітка практична спрямованість цієї навчальної дисципліни, адже в результаті ії вивчення студенти повинні були вміти гармонізувати мелодію або бас з неакордовими звуками, відхиленнями та модуляціями та грати за цифрованим басом [там саме, с. 8].

Звітом у Музичному технікумі були закриті й відкриті вечори, на яких викладачі та студенти певного класу демонстрували свою виконавську майстерність [там саме, арк. 27]. Важливим є той факт, що часто такі вечори проводилися виключно силами викладачів, що свідчить про постійну необхідність вдосконалювати свою виконавську майстерність. У збережених копіях програм цих вечорів неодноразово знаходимо концерти за участі таких 
викладачів як М. Литвиненко-Вольгемут, С. Савченко (вокал), О. РаниєцьІссерзон та О. Орська (фортепіано), Д. Френкін, С. Рапопорт, П. Мошкович (скрипка), В. Премислер і О. Губерман (альт), О. Браун (віолончель) [9].

При Музичному технікумі діяла й музична школа, яку очолював Овсій Маркович Губерман. Викладали в школі студенти технікуму [там саме, арк. 17].

Оперний театр, при якому діяв і хор, у 1924 р. здійснив постановки опер «Борис Годунов» М. Мусоргського, «Фауст» Ш. Гуно, «Кармен» Ж. Бізе, «Пікова Дама» та «Свгеній Онегін» П. Чайковського. У приміщенні театру проходили концерти Єврейського й Пролетарського хорів [7]. 14 березня 1921 р. у приміщенні театру пройшов виступ Айседори Дункан [7, арк. 59].

Влітку 1927 р. у Тульчині проходили гастролі Ленінградської опери, на які було отримано дозвіл Окружного репертуарного комітету, до складу якого входили Петраш, Городоцький та Дикий [11, арк. 527]. 3 протоколу засідання Окрреперткому випливає, що колектив виступив у місті 3 постановками «Травіати» Дж. Верді, «Русалки» О. Даргомижського, «Фауста» Ш. Гуно, «Бориса Годунова» М. Мусоргського, «Євгеній Онєгін» П. Чайковського, «Севільський цирульник» Дж. Россіні. Останню оперу було представлено також у містечку Вапнярка. На цьому ж засіданні було надано дозвіл віолончелісту Тесельському на влаштування концертів у містечках Чечельник, Ольгопіль і на Черномерській цукроварні. До його репертуару входили твори Й. С. Баха, К. Сен-Санса, С. Рахманінова, П. Чайковського, Ц. Кюї, А. Рубінштейна, Ф. Менедельсона-Бартольді та ін. [там саме].

3 архівних документів було відомо, що наприкінці 1920-х pp. пожвавилося музичне життя і серед учнівської молоді. Так, 13 травня 1928 р. у приміщенні Другої трудової школи відбувся платний вечірній концерт для учнів трудових шкіл, який підготували драматичні гуртки і хори шкіл багатьох трудових шкіл міста [10, арк. 71]. У грудні в приміщенні цієї ж Другої школи відбувся конщерт капели кобзарів з Уманщини для усіх учнів міста [там саме, арк. 200].

На початку 1930-х рр. на Вінниччині регулярно здійснювалися гастрольні тури відомих колективів. Так, у червні 1930 р. у Тульчині, Брацлаві відбулися концерти Державної капели «Думка» [12, арк. 484, арк. 504].

Наукова новизна полягає у наведенні нових історичних фактів концертної діяльності Вінниці, висвітленню творчої роботи Вінницького музичного технікуму, визначенні особливостей концертного репертуару, що були отримані в результаті дослідження, спираючись на періодичну пресу поч. XX ст. та матеріали Державного архіву вінницької області.

Висновки. Підсумовуючи огляд концертного життя Вінниччини першої третини XX ст., можна систематизувати його результати, враховуючи культурно-історичне тло розвитку регіону. Так, концертне життя Вінниччини пожвавлюється тоді, коли Вінниця стає 3 адміністративним центром Подільської губернії.

Особливу атмосферу творчого життя міста та області створюють концерти артистів московського Большого театру, ансамблю Московський фарс, Королівської фронтової трупи 3 Угорщини, вокалістів Клари Юнг 
з єврейською трупою оперети зі Сполучених Штатів Америки, київського театру «Дім інтермедії», Айседори Дункан, Державної капели «Думка».

Самобутні риси формування професійного культурного мистецтва краю пов'язані 3 відновленням діяльності великого симфонічного оркестру товариства «Просвіта» під орудою Б. Крижанівського, квартету Обермана, струнного оркестру, квартету Антона Гуммеля.

Особливе місце у концертному життя міста посідає діяльність хорових колективів. Так, у травні-червні 1919 р. розпочався набір до народного та дитячого хорів, а в серпні - до оперного хору при місцевому літературноартистичному товаристві. Організовується художня капела під керівництвом Г. Давидовського. У Місцевій пресі розміщено багато позитивних відгуків про концерти вищевказаних колективів.

Розвитку безпосередньо хорового мистецтва у Вінниці сприяла й діяльність у місті у 1920-их рр. Музичного технікуму та оперного театру. Велика увага приділялася таким предметам як постановка голосу, спеціальне фортепіано, сольфеджіо та теорія музики, що свідчить про професійний підхід викладачів технікуму та високу кваліфікацію його випуснкиків. Музичний технікум зробив свій внесок у концертне життя міста, систематично даючи концерти за участі таких викладачів як М. Литвиненко-Вольгемут, С. Савченко, О. РаниєцьІссерзон та О. Орська, Д. Френкін, С. Рапопорт, П. Мошкович, В. Премислер і О. Губерман, О. Браун. Відзначаються також і постановки опер всесвітньо відомих композиторів у місцевому оперному театрі.

Загалом, концертне життя Вінниччини в 1920-их pp. було дуже насиченим як завдяки новоствореним місцевим осередкам, так і гастролям окремих виконавців та колективів, що проходили не лише в центрі, але й на периферії краю. Концертна діяльність колективів, окремих виконавців та музичних інституцій Вінниччини першої третини XX ст. на тлі загальнонаціональних культурно-історичних процесів виявляє специфіку регіону, його музичного життя.

\section{Список використаних джерел}

1. Антошко М. О. Мистецьке життя Вінниччини 60-х років XIX - першої половини ХX століття в контексті художньої культури Поділля : дис. ... канд. мистецтвознав. : 26.00.01 / Антошко Марина Олегівна ; Нац. муз. акад. України ім. П. І. Чайковського. - Київ, 2010. - 191 арк.

2. Бермес I. Л. Український хоровий рух у контексті соціокультурних процесів XIX - початку XXI століття : дис. ... д-ра мистецтвознав. : 26.00.01 / Ірина Лаврентіївна Бермес ; Дрогобиц. держ. пед ун-т ім. Івана Франка. - Дрогобич, 2014. -435 c.

3. Борейко Г. Д. Культурне життя Рівненщини у 50-60 роки XX століття: тенденції та особливості розвитку : автореф. дис. ... канд. іст. наук : 26.00.01 / Галина Дмитрівна Борейко ; Нац. акад. керівних кадрів культури і мистецтв. Київ, 2010. - 16 с.

4. Бурдейна-Публіка Т. В. Становлення i розвиток професійних форм музичного життя Вінниччини як складової культури Подільського краю : дис. ... 
канд. мистецтвознавства : 26.00.01 / Тетяна Василівна Бурдейна-Публіка ; Львів. нац. муз. акад. ім. М. В. Лисенка. - Львів, 2010. - 284 с.

5. Матеріали Державного архіву Вінницької області. ДАВО. Ф. Р-254. Оп. 1. Спр. 600.

6. Матеріали Державного архіву Вінницької області. ДАВО. Ф. Р-254. Оп. 1. Спр. 623a.

7. Матеріали Державного архіву Вінницької області. ДАВО. Ф. Р-254. Оп. 1. Спр. 645.

8. Матеріали Державного архіву Вінницької області. ДАВО Ф. Р-254. Оп. 1. Спр. 651.

9. Матеріали Державного архіву Вінницької області. ДАВО. Ф. Р-254. Оп. 1. Спр. 1244.

10. Матеріали Державного архіву Вінницької області. ДАВО. Ф. Р-256. Оп. 1. Спр. 645.

11. Матеріали Державного архіву Вінницької області. ДАВО. Ф. Р-847. Оп. 1. Спр. 72.

12. Матеріали Державного архіву Вінницької області. ДАВО. Ф. Р-847. Оп. 1. Спр. 228.

13. Матеріали Державного архіву Вінницької області. ДАВО. Ф. Р-925. Оп. 2. Спр. 1 а.

14. Театр і музика // Слово Подолії. -1918. - 26 лип.

15. Хроніка // Вісти. - 1920. - 1 лип.

16. Хроніка // Шлях. - 1919. - 15 серп. - № 1.

17. Хроніка // Шлях. - 1919. - 19 серп. - № 4.

18. Хроніка // Шлях. - 1919. - 23 серп. - № 7.

19. Хроніка // Шлях. - 1919. - 13 верес. - № 23.

20. Черкашина О. В. Театр опери та балету і Державна консерваторія у Вінниці як феномени національної культури першої половини ХX ст. : дис. ... канд. мистецтвознав. : 26.00.01 / Олеся Валентинівна Черкашина ; Нац. акад. керівних кадрів культури і мистецтв. - Київ, 2012. - 241 с.

\section{References}

1. Antoshko, M. (2011). Vinnytsia region as a component of the artistic culture of Podillya of the 1960s and the first half of the 20th century. Candidate's thesis. P. Tchaikovsky National Music Academy of Ukraine.

2. Bermes, I. (2014). Ukrainian choral movement in the context of sociocultural processes of the 19th - early 21st century. D.Ed. Ivan Franko Drohobych State Pedagogical University.

3. Boreiko, H. (2010). Cultural life of Rivne region in the 50s-60s of the twentieth century: trends and peculiarities of development. Candidate's thesis. National Academy of Cultural and Arts Management.

4. Burdeina-Publika, T. (2010). Formation and development of professional forms of musical life of Vinnytsia region as a component of culture of Podillia. Candidate's thesis. M. Lysenko Lviv National Music Academy. 
5. Proceedings of the State Archives of Vinnytsia region. R-254. Op. 1. Case no. 600 .

6. Proceedings of the State Archives of Vinnytsia region. R-254. Op. 1. Case no. $623 \mathrm{a}$.

7. Proceedings of the State Archives of Vinnytsia region. R-254. Op. 1. Case no. 645 .

8. Proceedings of the State Archives of Vinnytsia region. R-254. Op. 1. Case no. 651.

9. Proceedings of the State Archives of Vinnytsia region. R-254. Op. 1. Case no. 1244.

10. Proceedings of the State Archives of Vinnytsia region. R-256. Op. 1. Case no. 645.

11. Proceedings of the State Archives of Vinnytsia region. R-847. Op. 1. Case no. 72. 12. Proceedings of the State Archives of Vinnytsia region. R-847. Op. 1. Case no. 228.

13. Proceedings of the State Archives of Vinnytsia region. R-925. Description. 2. Case no. 1a.

14. Theater and music (1918). Slovo Podolii [The word of Podolia], July 26.

15. Chronicle (1920). Visty [News], July 1.

16. Chronicle (1919). Shliakh [Way], August 15, no. 1.

17. Chronicle (1919). Shliakh [Way], August 19, no. 4.

18. Chronicle (1919). Shliakh [Way], August 23, no. 7.

19. Chronicle (1919). Shliakh [Way], September 13, no. 23.

20. Cherkashyna, O. (2012). Theater of Opera and Ballet and the State Conservatory in Vinnytsia as the phenomena of the national culture of the first half of the 20th century. Candidate's thesis. National Academy of Cultural and Arts Management.

(C) Сізова Н. C., 2018 